\title{
KERENTANAN SOSIAL EKONOMI DAN BIOFISIK DAERAH ALIRAN SUNGAI SOLO (Socio-economic and biophysical vulnerability of Solo Watershed)
}

\author{
Nur Ainun Jariyah ${ }^{1}$ dan Irfan Budi Pramono ${ }^{1}$ \\ ${ }^{1}$ Balai Penelitian dan Pengembangan Teknologi Pengelolaan Daerah Aliran Sungai \\ Jl. A. Yani PO Box 295 Pabelan,Telepon/Fax.: (+62 271) 716709/716959 \\ Email: nurainun_2513@yahoo.co.id \& Ibpramono@yahoo.com
}

Diterima: 25 Januari 2018; Direvisi: 21 Agustus 2018; Disetujui: 04 September 2018

\begin{abstract}
Increasing degradation of watershed ecosystem is a problem that needs to be resolved. Therefore, a study was conducted in order to determine the socio-economic and biophysical vulnerability of Solo watershed in relation to watershed management. This research was conducted in Solo Watershed. The collected data include primary and secondary data. The potential and vulnerability of socio-economic and biophysical were evaluated using the The Formulation of Watershed level Characterization System. The results of the study showed that (1) the socio-economic of the whole Solo watershed classify as moderate category, with the highest vulnerable district was Wonogiri due to high population density and high land vulnerability, (2) land vulnerability for the whole Solo watershed is in the medium category, with the most vulnerable land category was in Madiun and upstream Solo sub-watersheds, (3) the most prominent flood vulnerability was in the downstream of Solo sub-watershed, (4) the typology of watershed management was classified as high vulnerable because the territorial typology was in the very high vulnerable and the watershed typology was medium vulnerable. By knowing its vulnerability level, the rehabilitation program can be directed to areas with a high level of vulnerability.
\end{abstract}

Keywords: socio-economic; biophysical; vulnerability; watershed management

\begin{abstract}
ABSTRAK
Kerusakan ekosistem Daerah Aliran Sungai (DAS) yang semakin meningkat merupakan permasalahan yang perlu diselesaikan. Oleh karena itu telah dilakukan penelitian yang bertujuan untuk mengetahui kerentanan sosial ekonomi dan biofisik Daerah Aliran Sungai (DAS) Solo dalam kaitannya dengan pengelolaan DAS. Penelitian ini dilaksanakan di wilayah
\end{abstract}


DAS Solo. Data yang diambil meliputi data primer dan sekunder. Potensi dan kerentanan sosial ekonomi serta biofisik dievaluasi dengan menggunakan formulasi Sistem Karakterisasi Tingkat DAS (Tipologi DAS). Hasil penelitian menunjukkan bahwa (1) tipologi sosial ekonomi keseluruhan DAS Solo termasuk dalam kategori sedang dengan kabupaten yang sangat rentan adalah Wonogiri yang dipicu oleh kepadatan penduduk dan kerentanan lahan yang tinggi, (2) kerentanan lahan di DAS Solo secara menyeluruh termasuk dalam kategori sedang dengan tingkat kerentanan lahan yang paling tinggi di Sub DAS Kali Madiun dan Solo Hulu, (3) kerentanan banjir paling tinggi di Sub DAS Solo Hilir, (4) tipologi pengelolaan DAS Solo secara keseluruhan termasuk dalam kategori kerentanan tinggi karena tipologi kewilayahan termasuk dalam kategori kerentanan sangat tinggi dan tipologi DAS termasuk dalam kategori kerentanan sedang. Dengan mengetahui tingkat kerentanan suatu DAS maka kebijakan program rehabilitasi dapat diarahkan ke daerah-daerah yang mempunyai tingkat kerentanan yang tinggi.

Kata kunci: sosial ekonomi; biofisik; kerentanan; pengelolaan DAS

\section{PENDAhULUAN}

\section{Daerah Aliran Sungai (DAS) Solo} adalah DAS lintas propinsi yang merupakan salah satu dari 35 DAS di Jawa Tengah dan Jawa Timur yang pada saat ini dalam kondisi kritis (Keputusan Menteri Kehutanan Republik Indonesia No: SK. 328/Menhut-II/2009). Kondisi kritis ini disebabkan banyaknya praktik pertanian yang tidak mengindahkan kaidah konservasi serta adanya konversi lahan hutan dan pertanian ke lahan permukiman yang tidak diikuti oleh usaha konservasi tanah dan air serta belum jelasnya arah dan implementasi pembangunan dalam mengatasi permasalahan sumberdaya alam secara nasional (Nugroho, 2003 ; Budiarti, Gravitiani, \& Mujiyo, 2017; Krisnohadi, 2011; Ariani \& Harini, 2012). Selain itu menurut Gautama (2008) kerusakan DAS antara lain timbul akibat: 1) perencanaan bentuk penggunaan lahan dan praktek pengelolaan yang tidak sesuai, 2) pertambahan jumlah penduduk baik secara alami maupun buatan, 3) kemiskinan dan kemerosotan ekonomi akibat keterbatasan sumber daya manusia, sumber daya alam dan mata pencaharian, 4) kelembagaan yang ada kurang mendukung pelayanan kepada para petani di hulu/ hutan, 5) kebijakan perlindungan dan peraturan legislatif, tidak membatasi kepemilikan/ penggunaan lahan, 6) ketidakpastian penggunaan hak atas tanah secara de facto pada lahan hutan.

Kondisi DAS yang kritis diindikasikan oleh banyaknya bencana mulai dari erosi, banjir, tanah longsor sampai hilangnya sumber mata air, kekeringan dan perubahan fungsi tata guna lahan sehingga dapat mengganggu kehidupan masyarakat (Paimin, Sukresno, \& Purwanto, 2010 ; Lukman \& Wienarto, 2008; Cahyo Wibowo et al., 2014). Perubahan fungsi lahan di daerah hulu memberikan dampak negatif terhadap daerah hilir (Rahman, Harisuseno, \& Sisinggih, 2012; Purbawiyatna et al., 2012; 
Atmojo, 2008). Oleh karena itu diperlukan pengelolaan DAS yang pada prinsipnya mengoptimalkan penggunaan lahan untuk berbagai kepentingan secara rasional (Susetyaningsih, 2012; Sudarwanto, 2015). Menurut Kementerian Pekerjaan Umum, DAS Solo merupakan DAS lintas propinsi yang mempunyai banyak permasalahan diantaranya banjir, kekeringan, erosi, sedimentasi, intrusi air laut, kualitas air, dan lain sebagainya (Balai Besar Wilayah Sungai Bengawan Solo, 2012).

Permasalahan-permasalahan yang ada dapat diminimalisir, apabila masyarakat umumnya dan instansi terkait khususnya mengetahui potensi dan kerentanan DAS Solo. Oleh karena itu penelitian ini mencoba mengevaluasi potensi dan kerentanan sumber daya alam dan sosial ekonomi DAS Solo. Potensi adalah kemampuan yang mempunyai kemungkinan untuk dikembangkan. Kerentanan didefinisikan sebagai kondisi karakteristik geografis, sosial, ekonomi, politik, budaya, biologis dan teknologi suatu masyarakat di suatu wilayah untuk jangka waktu tertentu, yang dapat mengurangi kemampuan dari masyarakat untuk mencegah, meredam dan mencapai kesiapan ataupun untuk menanggapi dampak bahaya tertentu (Cannon, T., 1994 dalam Wismarini \& Sukur, 2015). Tujuan dari penelitian ini adalah mengevaluasi kerentanan sosial ekonomi dan biofisik untuk bahan masukan kepada instansi terkait dalam pengelolaan DAS Solo.

\section{BAHAN DAN METODE}

\section{A. Waktu dan Lokasi Penelitian}

Penelitian ini dilaksanakan di DAS Solo dari bulan Maret-Desember 2012. DAS Solo merupakan DAS terluas di Wilayah Sungai (WS) Bengawan Solo yang meliputi Sub DAS Solo Hulu, Sub DAS Kali Madiun, dan Sub DAS Solo Hilir dengan luas masing-masing berturut-turut \pm 6.072 $\mathrm{km}^{2}$ dan $\pm 3.753 \mathrm{~km}^{2}$, dan $\pm 6.273 \mathrm{~km}^{2}$ (Balai Besar Wilayah Sungai Bengawan Solo, 2012).

Sub DAS Solo hulu meliputi wilayah Kabupaten Wonogiri, Karanganyar, Klaten, Sragen, Ngawi, Boyolali dan Kota Surakarta. Sub DAS Madiun meliputi wilayah Kabupaten Madiun, Ngawi, Ponorogo, Magetan, dan Wonogiri. Sub DAS Solo hilir meliputi wilayah Kabupaten Blora, Bojonegoro, Lamongan, Tuban, dan Gresik. Perincian pembagian DAS Solo dapat dilihat pada Gambar 1.

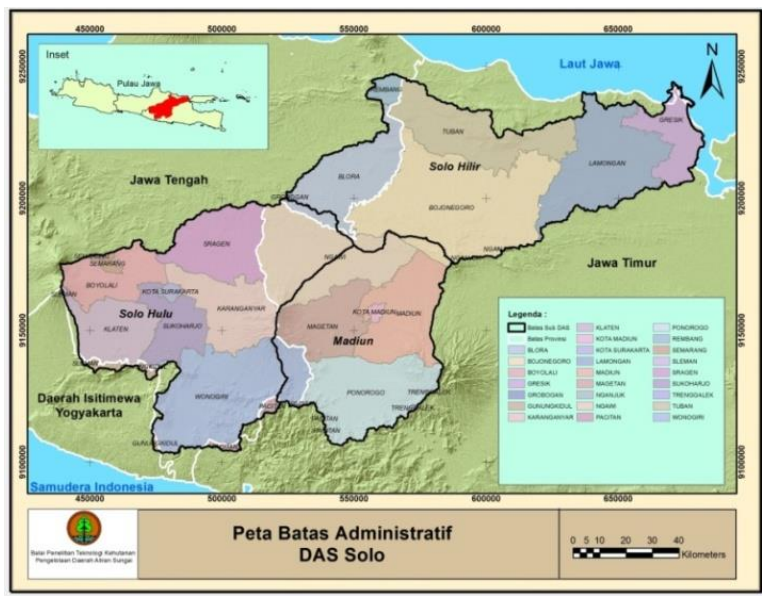

Gambar (Figure) 1. Peta batas administrasi DAS Solo (Map of adminis-trative boundary of Solo Watershed)

Sumber (Source): Balai Penelitian Teknologi Kehutanan Pengelolaan DAS (2012) 


\section{B. Pengumpulan Data}

Data yang diambil meliputi data primer dan data sekunder. Pengambilan data sosial ekonomi dilakukan dengan melakukan wawancara dengan indepth interview dengan tokoh kunci (key person). Key person adalah Kepala Dinas dan Kepala seksi yang menangani pengelolaan DAS. Pengumpulan data primer biofisik melalui survei berdasarkan citra satelit dan Google Earth serta peta Rupa Bumi Indonesia tahun 2001 untuk identifikasi penutupan lahan aktual. Batas DAS, kemiringan lereng, dan morfometri DAS diperoleh dari Digital Elevation Model (DEM). Identifikasi erosi, dan banjir serta land cover dilihat langsung ke lapangan dengan menggunakan check list. Untuk mendukung data primer juga dilakukan pengambilan data sekunder di instansi terkait seperti Balai Sungai, Balai Pengelolaan Daerah Aliran Sungai dan Hutan Lindung (BPDASHL) Solo, Kementerian Pekerjaan Umum, Dinas Pertanian, Dinas Kehutanan, Kesejahteraan, Pembangunan, dan Perlindungan Masyarakat (Kesbanglinmas) dan Badan Pusat Statistik (BPS).

\section{Analisis Data}

Analisis data dilakukan dengan menggunakan deskriptif kuantitatif yaitu dengan menganalisis kerentanan dan potensi berdasarkan parameter dan berdasarkan pembobotan. Potensi dan kerentanan sosial ekonomi dan biofisik diperoleh dengan menggunakan Formulasi Sistem Karakterisasi Tingkat DAS (Paimin, Pramono, Purwanto, \& Indrawati, 2012). Skala kerentanan untuk masing-masing kerentanan adalah skala 5 (sangat rentan), skala 4 (rentan), skala 3 (sedang), skala 2 (agak rentan), dan skala 1 (tidak rentan).

Untuk mendapatkan masing-masing tingkat kerentanan tersebut, tahapan yang harus dilakukan adalah mencari:

1. Kerentanan penduduk terhadap lahan dengan parameter kepadatan penduduk dan struktur ekonomi. Pengukuran dilakukan dengan menggunakan Tabel 1.

2. Kerentanan ekonomi DAS dengan parameter pendapatan dan pertumbuhan ekonomi. Pengukuran kerentanan ekonomi dilakukan dengan menggunakan Tabel 2 .

Tabel (Table) 1. Skala kerentanan penduduk terhadap lahan (The scale of vulnerability of the population to the

\begin{tabular}{|c|c|c|c|}
\hline \multirow{2}{*}{$\begin{array}{c}\text { Kepadatan penduduk (Population } \\
\text { density) } \\
\left(\text { Orang } / \mathrm{km}^{2}\right) \\
\left(\text { People } / \mathrm{km}^{2}\right)\end{array}$} & \multicolumn{3}{|c|}{ Struktur ekonomi (Economic structure) } \\
\hline & $\begin{array}{l}\text { Pertanian (5) } \\
\text { (Agriculture) }\end{array}$ & $\begin{array}{l}\text { Industri (3) } \\
\text { (Industrial) }\end{array}$ & Jasa (1) (Services) \\
\hline Jarang (Rarely) $(<250)$ & 3 & 2 & 1 \\
\hline Sedang (Medium) (250-400) (2) & 4 & 3 & 2 \\
\hline Padat (Dense) (> 400) & 5 & 4 & 3 \\
\hline
\end{tabular}

Sumber (Source): Paimin et al. (2012)

Keterangan (Remark): Angka dalam kurung ( ) menunjukkan nilai skor pada setiap parameter (The Numbers in brackets () indicate the scores of each parameter). 
Vol. 2 No. 2, Oktober 2018 : 89-110

Tabel (Table) 2. Skala kerentanan ekonomi DAS (The scale of vulnerability of the watershed economy)

\begin{tabular}{|c|c|c|c|c|c|}
\hline \multirow{2}{*}{$\begin{array}{l}\text { Pendapatan } \\
\text { (Income) }\end{array}$} & \multicolumn{5}{|c|}{ Pertumbuhan ekonomi (Economic growth) } \\
\hline & $\begin{array}{c}\text { Pentil 5 } \\
(>7,81 \%) \\
(1)\end{array}$ & $\begin{array}{c}\text { Pentil } 4 \\
(6,33 \%-7,81 \%) \\
(2)\end{array}$ & $\begin{array}{c}\text { Pentil 3 } \\
(4,85 \%-6,32 \%) \\
(3)\end{array}$ & $\begin{array}{c}\text { Pentil } 2 \\
(3,37 \%-4,84 \%) \\
(4)\end{array}$ & $\begin{array}{c}\text { Pentil } 1 \\
(<3,37 \%) \\
(5)\end{array}$ \\
\hline$>1,5$ SK (1) & 1 & 1,5 & 2 & 2,5 & 3 \\
\hline $1,26-1,5$ SK (2) & 1,5 & 2 & 2,5 & 3 & 3,5 \\
\hline $1,1-1,25$ SK (3) & 2 & 2,5 & 3 & 3,5 & 4 \\
\hline 0,67-1 SK (4) & 2,5 & 3 & 3,5 & 4 & 4,5 \\
\hline$<0,67$ SK (5) & 3 & 3,5 & 4 & 4,5 & 5 \\
\hline
\end{tabular}

Sumber (Source): Paimin et al. (2012)

Keterangan (Remarks):

- SK (detail SK) : Standar Kemiskinan. Angka dalam kurung ( ) menunjukkan nilai skor pada setiap parameter (Poverty standards. The numbers in brackets () indicate the value of scores on each parameter)

- Pentil : Perlima (Percentile)

3. Kerawanan/ sensitivitas kewilayahan pengelolaan DAS dengan parameter luas DAS dan kewilayahan administrasi. Pengukuran dilakukan dengan menggunakan Tabel 3.

4. Kerentanan lahan terhadap erosi. Parameter yang dicari adalah bentuk/sistem lahan dan penutupan lahan. Pengukuran dilakukan dengan menggunakan Tabel 4.

5. Nilai kerentanan daerah tangkapan air ini merupakan nilai rata-rata dari tipologi lahan dan nilai tipologi sosial ekonomi. Tingkat kerentanannya dengan menggunakan klasifikasi Tabel 5.

Tabel (Table) 3. Skala kerawanan/sensitivitas kewilayahan pengelolaan DAS (The scale of vulnerability/ sensitivity of territorial watershed management)

\begin{tabular}{lccc}
\hline Luas DAS (ha) & \multicolumn{2}{c}{ Kewilayahan administrasi (Territorial administration) } \\
\cline { 2 - 4 } (Watershed area) & $\begin{array}{c}\text { Dalam kabupaten } \\
\text { (In district) }\end{array}$ & $\begin{array}{c}\text { Lintas kabupaten/ dalam } \\
\text { propinsi (Cross district) } \\
\text { in province) }\end{array}$ & $\begin{array}{c}\text { Lintas propinsi (Cross } \\
\text { province) }\end{array}$ \\
\hline $\begin{array}{l}\text { Kecil (Small) } \\
(<0,15 \text { juta) }\end{array}$ & 1 & 2 & 3 \\
$\begin{array}{l}\text { Sedang (Moderate) } \\
(0,15-0,5 \text { juta) }\end{array}$ & 2 & 3 & 4 \\
$\begin{array}{l}\text { Luas (Broad) } \\
(>0,5 \text { juta) }\end{array}$ & 3 & 4 & 5 \\
\hline Sumber (Source): Paimin et al. (2012) & &
\end{tabular}

Sumber (Source): Paimin et al. (2012) 
Tabel (Table) 4. Skala kerentanan/sensitivitas lahan terhadap erosi (The scale of vulnerability / sensitivity of land to erosion)

\begin{tabular}{|c|c|c|c|c|c|c|}
\hline \multirow{2}{*}{$\begin{array}{lr}\text { Bentuk/ } & \text { sistem } \\
\text { lahan } & \text { (Land } \\
\text { system) } & \end{array}$} & \multicolumn{6}{|c|}{ Penutupan lahan (Land cover) } \\
\hline & $\begin{array}{c}\text { Air payau } \\
\text { (Brackish } \\
\text { water), air } \\
\text { tawar } \\
\text { (Fresh } \\
\text { water), } \\
\text { gedung } \\
\text { (Building) } \\
\text { (1) }\end{array}$ & $\begin{array}{c}\text { Hutan } \\
\text { lindung } \\
\text { (Protection } \\
\text { forest), hutan } \\
\text { konservasi } \\
\text { (Conservation } \\
\text { forest) } \\
\text { (1) }\end{array}$ & $\begin{array}{l}\text { Hutan } \\
\text { produksi/ } \\
\text { perkebunan } \\
\text { (Production } \\
\text { forests/ } \\
\text { plantations) } \\
\text { (2) }\end{array}$ & $\begin{array}{c}\text { Sawah } \\
\text { (Field), } \\
\text { rumput } \\
\text { (Grass), } \\
\text { semak/ } \\
\text { belukar } \\
\text { (Shrubs) } \\
\text { (3) }\end{array}$ & $\begin{array}{c}\text { Pemukiman } \\
\text { (Settlement) } \\
\text { (4) }\end{array}$ & $\begin{array}{c}\text { Tegal (Dry } \\
\text { fields), } \\
\text { tanah } \\
\text { berbatu } \\
\text { (Rocky } \\
\text { soils) (5) }\end{array}$ \\
\hline $\begin{array}{l}\text { Rawa-rawa } \\
\text { (Swamps), } \\
\text { Pantai (Beach) } \\
\text { (1) }\end{array}$ & 1 & 1 & 1 & 1 & 1 & 1 \\
\hline $\begin{array}{l}\text { Dataran alluvial } \\
\text { (Alluvial plains), } \\
\text { lembah alluvial } \\
\text { (Alluvial } \\
\text { valley)(2) }\end{array}$ & 1 & 1,5 & 1,5 & 2 & 2 & 2,5 \\
\hline $\begin{array}{l}\text { Dataran } \\
\text { (Plains)(3) }\end{array}$ & 1 & 2 & 2,5 & 3 & 3,5 & 4 \\
\hline $\begin{array}{l}\text { Kipas dan lahar } \\
\text { (Fan and lava), } \\
\text { teras-teras } \\
(\text { Terrace })(4)\end{array}$ & 1 & 2,5 & 3 & 3,5 & 4 & 4,5 \\
\hline $\begin{array}{l}\text { pegunungan dan } \\
\text { perbukitan (The } \\
\text { mountains and } \\
\text { hills) (5) }\end{array}$ & 1 & 3 & 3,5 & 4 & 4,5 & 5 \\
\hline
\end{tabular}

Keterangan (Remark): Angka dalam kurung merupakan nilai/ skor dari parameter yang bersangkutan (The numbers in brackets () indicate the value of scores on each parameter)

Sumber (Source): $\quad$ Paimin et al. (2012)

Tabel (Table) 5. Klasifikasi tipologi atau kerentanan lahan tingkat DAS (Classification of typology or vulnerability of watershed)

\begin{tabular}{lrl}
\hline \multicolumn{1}{c}{ Kategori } & Nilai & Tingkat Kerentanan \\
\hline Sangat tinggi (Very high) & 4,3 & Sangat rentan \\
Tinggi (High) & $3,5-4,3$ & Rentan \\
Sedang (Moderate) & $2,6-3,4$ & Sedang \\
Rendah (Low) & $1,7-2,5$ & Agak rentan \\
Sangat rendah (Very low) & $<1,7$ & Tidak rentan \\
\hline
\end{tabular}

Sumber (Source): Paimin et al. (2012)

Tipologi Pengelolaan DAS (Tabel 7) dapat dilihat dari tipologi DAS dan tipologi kewilayahan (Tabel 6). Tipologi DAS mencerminkan kondisi suatu DAS baik dari kondisi daerah tangkapan airnya maupun kondisi banjirnya. Tipologi DAS diperoleh dari hasil interaksi antara tipologi Daerah Tangkapan Air (DTA) dan tipologi banjir. Nilai kerentanan DAS merupakan nilai rata-rata tipologi DTA dan nilai tipologi banjir, yang klasifikasinya seperti Tabel 5 . 
Vol. 2 No. 2, Oktober $2018: 89-110$

Tabel (Table) 6. Skala kerentanan/ sensitivitas kewilayahan pengelolaan DAS (Vulnerability/ sensitivity scale of territorial watershed management)

Luas DAS (ha)

(Area)
Kewilayahan Administrasi Dominan

(Dominant administrative territory)

\begin{tabular}{lcc}
\hline Dalam Kabupaten & Lintas kabupaten/ dalam & Lintas Propinsi \\
(In the district) & propinsi & (Cross province)
\end{tabular}

(Cross district/ in the province)

\begin{tabular}{llll}
\hline Kecil $($ Area $)(<0,15$ juta) & 1 & 2 & 3 \\
Sedang (Medium) $(0,15-0,5$ juta $)$ & 2 & 3 & 4 \\
Luas (Large) $(>0,5$ juta) & 3 & 4 & 5
\end{tabular}

Sumber (Source): Paimin et al. (2012)

Tabel (Table) 7. Tipologi pengelolaan DAS (Typology of watershed management)

\begin{tabular}{cccccc}
\hline Tipologi & \multicolumn{5}{c}{ Tipologi DAS (Typology of watershed) } \\
\hline Kewilayahan (Typology of & $<1,7$ (sangat & $1,7-2,5$ & $2,6-3,4$ & $3,5-4,3$ & $>4,3$ (sangat \\
territorial) & $\begin{array}{c}\text { rendah) (Very } \\
\text { low) }\end{array}$ & $\begin{array}{c}\text { (rendah) } \\
(\text { Low) }\end{array}$ & $\begin{array}{c}\text { (sedang) } \\
\text { (Average) }\end{array}$ & $\begin{array}{c}\text { (tinggi) } \\
\text { (Hight) }\end{array}$ & $\begin{array}{c}\text { tingi) (Very } \\
\text { hight) }\end{array}$ \\
$\begin{array}{c}\text { Sangat rendah -rendah } \\
\text { (Very low-low) }\end{array}$ & $<1,7$ & $<1,7$ & $1,7-2,5$ & $1,7-2,5$ & $2,6-3,4$ \\
Sedang (Average) & $<1,7$ & $2,6-3,4$ & $2,6-3,4$ & $3,5-4,3$ & $>4,7$ \\
Tinggi-sangat tinggi & $1,7-2,5$ & $2,6-3,4$ & $2,6-3,4$ & $3,5-4,3$ & $>4,7$ \\
(Hight-very hight) & & & & &
\end{tabular}

Sumber (Source): Paimin et al. (2012)

\section{HASIL DAN PEMBAHASAN}

\section{A. Gambaran Umum DAS Solo}

DAS Solo merupakan salah satu DAS prioritas yang perlu dilakukan pembenahan untuk peningkatan kualitas DAS. Beberapa permasalahan DAS Solo diantaranya adalah banjir, kekeringan, erosi, sedimentasi, intrusi air laut, kualitas air, dan lain sebagainya yang disebabkan antara lain: 1) terus menurunnya kondisi hutan, 2) kerusakan DAS yang disebabkan oleh penebangan liar dan konversi lahan yang menimbulkan kerusakan ekosistem dalam tatanan DAS, 3) lemahnya penegakan hukum dalam pembalakan liar, dan 4) masih rendahnya kesadaran masyarakat dalam pemeliharaan lingkungan (Balai Besar Wilayah Sungai Bengawan Solo, 2012).

\section{B. Kerentanan Sosial Ekonomi}

Kerentanan sosial ekonomi dapat dilihat dari kepadatan penduduk. Semakin tinggi kepadatan penduduk (>400 orang/ $\mathrm{km}^{2}$ ) menunjukkan kerentanan penduduk terhadap lahan tinggi. Jumlah penduduk paling tinggi adalah Kabupaten Klaten, wilayah paling luas adalah Kabupaten Bojonegoro, sedangkan kepadatan penduduk tertinggi adalah Kotamadya Surakarta. Secara keseluruhan semua kabupaten yang termasuk dalam wilayah DAS Solo masuk dalam kategori padat yaitu kepadatan penduduk lebih dari 400 orang/ $\mathrm{km}^{2}$.

Produk Domestik Regional Bruto (PDRB) berdasarkan harga konstan digunakan untuk mengetahui pertumbuhan ekonomi dari tahun ke tahun. Pada penelitian ini yang digunakan 
adalah tahun 2009 dan 2010. Terlihat bahwa pertumbuhan ekonomi paling tinggi adalah Kabupaten Bojonegoro yaitu mencapai $11,87 \%$. Hanya 5 kabupaten yang pertumbuhan ekonominya berada di atas pertumbuhan ekonomi Indonesia (6,5\%) yaitu Kabupaten Bojonegoro, Gresik, Karanganyar, Lamongan, dan Kota Madiun (Bank Indonesia, 2011). Adapun kabupaten lainnya pertumbuhan ekonomi masih berada di bawah pertumbuhan ekonomi Indonesia.

Namun demikian pertumbuhan ekonomi Kabupaten Wonogiri dan Kabupaten Klaten sangat tertinggal dibandingkan dengan daerah lain. Secara umum rata-rata pertumbuhan ekonomi kabupaten di DAS Solo adalah 5,86\% (masih di bawah pertumbuhan ekonomi nasional yaitu sebesar 6,5\%). Melihat hal tersebut tentu saja diperlukan upaya untuk dapat meningkatkan pertumbuhan ekonomi masing-masing daerah khususnya yang masih di bawah pertumbuhan ekonomi nasional seperti Blora, Boyolali, Klaten, Madiun, Magetan, Ngawi, Ponorogo, Sragen, Sukoharjo, Wonogiri, dan Tuban.

Pendapatan per kapita juga memberikan gambaran kerentanan sosial ekonomi. Pendapatan per kapita tertinggi di DAS Solo adalah Kabupaten Gresik dengan sumbangan tertinggi dari sektor industri pengolahan sebesar 50\%. Pendapatan per kapita kabupaten di DAS Solo berada di atas batas kemiskinan.
Batas kemiskinan adalah tingkat minimum pendapatan yang dianggap perlu dipenuhi untuk memperoleh standar hidup yang mencukupi suatu negara. Di Indonesia batas kemiskinan yang digunakan adalah sebesar Rp.4.645.920 per kapita (BPS, 2018). Batas kemiskinan ini digunakan sebagai perangkat ekonomi untuk mengukur rakyat miskin dan mempertimbangkan pembaruan sosio-ekonomi, misalnya program peningkatan kesejahteraan dan asuransi pengangguran untuk menanggulangi kemiskinan (BPS, 2013).

Kabupaten dengan pendapatan per kapita tinggi adalah Kabupaten Gresik, Kota Madiun, Kota Surakarta, dan Kabupaten Tuban. Sektor yang memberikan sumbangan tinggi untuk pendapatan per kapita masing-masing daerah tersebut adalah didominasi bidang industri pengolahan dan perdagangan, hotel, restoran. Sementara itu kabupaten yang berada di bawah batas kemiskinan adalah Kabupaten Wonogiri dan Blora.

Kedua kabupaten tersebut sumbangan pendapatan per kapita didominasi dari sektor pertanian $( \pm 50 \%)$. Hal ini menunjukkan bahwa sektor pertanian untuk saat ini belum bisa menjanjikan untuk peningkatan pendapatan. Hal ini dimungkinkan karena hasil pertanian hanya ditujukan untuk mencukupi kebutuhan sehari-hari saja, belum untuk komersial. Secara lebih jelas pendapatan per kapita masing-masing daerah dapat dilihat pada Tabel 8. 
Vol. 2 No. 2, Oktober 2018 : 89-110

Tabel (Table) 8. Pendapatan dibandingkan dengan batas kemiskinan provinsi di DAS Solo (Income are compared to provincial poverty thresholds in Solo Watershed)

\begin{tabular}{|c|c|c|c|c|}
\hline $\begin{array}{l}\text { No } \\
(\mathrm{No})\end{array}$ & $\begin{array}{c}\text { Kabupaten/ Kota } \\
\text { (District) }\end{array}$ & $\begin{array}{l}\text { Batas kemiskinan } \\
\text { provinsi (Province } \\
\text { poverty thresholds) } \\
\mathrm{Rp} / \text { kapita/th } \\
\text { (Rp/capita/year) }\end{array}$ & $\begin{array}{l}\text { Pendapatan per } \\
\text { kapita (Income } \\
\text { per capita) } \\
\text { Rp/jiwa } \\
\text { (Rp/people) }\end{array}$ & $\begin{array}{l}\text { Dibandingkan } \\
\text { dengan batas } \\
\text { kemiskinan } \\
\text { (Compare with the } \\
\text { poverty threshold) }\end{array}$ \\
\hline 1 & Boyolali & 2.667 .924 & $4.462 .048,07$ & 1,67 \\
\hline 2 & Karanganyar & 2.667 .924 & $6.220 .186,94$ & 2,33 \\
\hline 3 & Klaten & 2.667 .924 & 3.710.211,70 & 1,39 \\
\hline 4 & Sragen & 2.667 .924 & $3.486 .638,00$ & 1,31 \\
\hline 5 & Sukoharjo & 2.667 .924 & $5.888 .864,29$ & 2,21 \\
\hline 6 & Surakarta & 2.667 .924 & $10.221 .352,96$ & 3,83 \\
\hline 7 & Wonogiri & 2.667 .924 & $2.407 .782,58$ & 0,90 \\
\hline 8 & Ngawi & 2.798 .424 & $3.494 .460,26$ & 1,25 \\
\hline 9 & Kota Madiun & 2.798 .424 & $11.140 .256,43$ & 3,98 \\
\hline 10 & Madiun & 2.798 .424 & $3.988 .675,93$ & 1,43 \\
\hline 11 & Magetan & 2.798 .424 & 4.787.569,95 & 1,71 \\
\hline 12 & Ponorogo & 2.798 .424 & $3.894 .694,75$ & 1,39 \\
\hline 13 & Blora & 2.798 .424 & $2.630 .751,28$ & 0,99 \\
\hline 14 & Bojonegoro & 2.798 .424 & $6.717 .689,57$ & 2,40 \\
\hline 15 & Lamongan & 2.798 .424 & $5.250 .853,85$ & 1,88 \\
\hline 16 & Tuban & 2.798 .424 & $10.221 .325,96$ & 3,65 \\
\hline \multirow[t]{2}{*}{17} & Gresik & 2.798 .424 & $14.506 .378,58$ & 5,18 \\
\hline & Rata-rata (average) & 2.737 .012 & $6.060 .571,42$ & 2,21 \\
\hline
\end{tabular}

Sumber (Source): Analisis data sekunder (Secondary data analysis) (BPS, 2011a ; BPS, 2011b)

1. Kerentanan Penduduk Terhadap Lahan

Kabupaten yang masuk dalam kategori sangat rentan adalah Boyolali, Sragen, Wonogiri, Ngawi, Madiun, Magetan, Ponorogo, Blora, dan Lamongan. Hal ini dapat dilihat dari struktur ekonomi masing-masing kabupaten tersebut, didominasi oleh sektor pertanian dan kepadatan penduduk yang tinggi (Tabel 9). Hal ini menyebabkan kerentanan penduduk terhadap lahan tinggi karena masih banyak penduduk yang mengeksploitasi lahan untuk lahan pertanian. Pertanian merupakan mata pencaharian utama sebagian besar penduduk di daerah tersebut. Namun demikian, selama pertanian dilakukan sesuai dengan kaidah konservasi, hal itu tidak akan menimbulkan permasalahan di DAS. Selain itu kepadatan penduduk perlu dikurangi dengan mendorong adanya program transmigrasi atau program Keluarga Berencana (KB).

\section{Kerentanan Ekonomi}

Kerentanan ekonomi beberapa kabupaten yang masuk dalam kategori sedang sampai rentan yaitu Kabupaten Wonogiri, Klaten, dan Blora. Sementara itu Kabupaten Wonogiri kerentanannya paling tinggi. Hal ini terjadi karena PDRB Kabupaten Wonogiri pertahun dibandingkan dengan garis kemiskinan propinsi sebesar 0,9 kali dari garis kemiskinan. Selain itu pertumbuhan ekonomi Kabupaten Wonogiri sebesar 3,14\% masih di bawah pertumbuhan ekonomi nasional sebesar 6,5\% dan di bawah pertumbuhan rata-rata kabupaten di DAS Solo sebesar $5,86 \%$. 
Tabel (Table) 9. Kerentanan penduduk terhadap lahan DAS Solo (The vulnerability of the population to Solo Watershed)

\begin{tabular}{|c|c|c|c|c|}
\hline $\begin{array}{l}\text { No } \\
(\mathrm{No})\end{array}$ & $\begin{array}{c}\text { Kabupaten/ Kota } \\
\text { (District) }\end{array}$ & $\begin{array}{c}\text { Kepadatan Penduduk } \\
\text { (Population density) } \\
\text { Jiwa } / \mathrm{km}^{2} \\
\left(\text { People } / \mathrm{km}^{2}\right) \\
\end{array}$ & $\begin{array}{c}\text { Struktur ekonomi } \\
\text { (Economic } \\
\text { structure) }\end{array}$ & $\begin{array}{c}\text { Kerentanan } \\
\text { (Vulnerability) } \\
\text { Skala 1-5 } \\
\text { (Scale 1-5) } \\
\end{array}$ \\
\hline 1 & Boyolali & 939,65 & Pertanian & 5 \\
\hline 2 & Karanganyar & $1.134,96$ & Industri & 4 \\
\hline 3 & Klaten & $1.994,57$ & Jasa & 3 \\
\hline 4 & Sragen & 938,31 & Pertanian & 5 \\
\hline 5 & Sukoharjo & $1.814,98$ & Industri & 4 \\
\hline 6 & Surakarta & $11.338,26$ & Jasa & 3 \\
\hline 7 & Wonogiri & 607,88 & Pertanian & 5 \\
\hline 8 & Ngawi & 631,00 & Pertanian & 5 \\
\hline 9 & Kota Madiun & $5.144,87$ & Jasa & 3 \\
\hline 10 & Madiun & 655,16 & Pertanian & 5 \\
\hline 11 & Magetan & 900,69 & Pertanian & 5 \\
\hline 12 & Ponorogo & 623,48 & Pertanian & 5 \\
\hline 13 & Blora & 454,89 & Pertanian & 5 \\
\hline 14 & Bojonegoro & 524,47 & Industri & 4 \\
\hline 15 & Lamongan & 650,41 & Pertanian & 5 \\
\hline 16 & Tuban & 683,69 & Jasa & 3 \\
\hline \multirow[t]{2}{*}{17} & Gresik & 988,07 & Industri & 4 \\
\hline & Rata-rata & & & 4 \\
\hline
\end{tabular}

Sumber (Source): Analisis data (Data analysis), 2012

Tabel (Table) 10. Kerentanan ekonomi DAS Solo (Economic vulnerability of Solo Watershed)

\begin{tabular}{llccc}
\hline $\begin{array}{c}\text { No } \\
(\mathrm{No})\end{array}$ & \multicolumn{1}{c}{$\begin{array}{c}\text { Kabupaten/kota } \\
\text { (District) }\end{array}$} & $\begin{array}{c}\text { Pendapatan } \\
\text { (Income) }\end{array}$ & $\begin{array}{c}\text { Pertumbuhan ekonomi (\%) } \\
\text { (Economic growth) }\end{array}$ & $\begin{array}{c}\text { Kerentanan skala 1-5 } \\
\text { (Vulnerability) }\end{array}$ \\
\hline 1 & Boyolali & 1,67 & 3,61 & 2,5 \\
2 & Karanganyar & 2,33 & 7,40 & 1,5 \\
3 & Klaten & 1,39 & 2,04 & 3,5 \\
4 & Sragen & 1,31 & 6,09 & 2,5 \\
5 & Sukoharjo & 2,21 & 4,65 & 2,5 \\
6 & Surakarta & 3,83 & 5,94 & 2 \\
7 & Wonogiri & 0,90 & 3,14 & 4,5 \\
8 & Ngawi & 1,25 & 6,09 & 3 \\
9 & Kota Madiun & 3,98 & 6,93 & 1,5 \\
10 & Madiun & 1,43 & 5,92 & 2,5 \\
11 & Magetan & 1,71 & 5,09 & 2 \\
12 & Ponorogo & 5,78 & 2 \\
13 & Blora & 1,39 & 5,04 & 3,5 \\
14 & Bojonegoro & 0,99 & 11,87 & 1 \\
15 & Lamongan & 2,40 & 6,89 & 1,5 \\
16 & Tuban & 1,88 & 6,22 & 2 \\
17 & Gresik & 3,65 & 6,86 & 1,5 \\
\hline
\end{tabular}

Keterangan (Remark): Skala kerentanan bukan bilangan bulat karena terletak antara skala 1 dan 2, skala 2 dan 3 dst (sesuai Tabel 2) (The scale of vulnerability is not integer value because between scale of 1 to 2, 2 to 3 and etc (according to Table 2))

Sumber (Source): $\quad$ Analisis data (Data analysis), 2012 
Vol. 2 No. 2, Oktober 2018 : 89-110

\section{Tipologi Sosial Ekonomi}

Secara umum tipologi sosial ekonomi DAS Solo masuk dalam kategori kerentanan sedang. Kabupaten yang sangat rentan adalah Kabupaten Wonogiri. Hal ini dilihat dari kerentanan penduduk terhadap lahan dan kerentanan ekonomi masuk dalam kategori sangat rentan. Sementara itu Kabupaten Boyolali, Sragen, Ngawi, Madiun, Magetan, Ponorogo, dan Blora masuk dalam kategori rentan. Hampir 50\% wilayah DAS Solo, tipologi sosial ekonominya masuk dalam kategori rentan.

Hal ini harus menjadi perhatian khusus dalam mengelola DAS Solo karena kerentanan penduduk terhadap lahan dan kerentanan ekonominya masuk kategori rentan. Kabupaten-kabupaten tersebut masuk dalam DAS Solo hulu dan DAS Kali Madiun, penyebab utamanya adalah kepadatan penduduk yang tinggi dan struktur ekonomi yang didominasi oleh pertanian. Hal ini yang menjadi perhatian khusus untuk pengambil kebijakan apa yang perlu dilakukan.

Kepadatan penduduk yang tinggi bisa dilakukan dengan transmigrasi atau program pembatasan kelahiran untuk mengurangi kepadatan penduduk yang tinggi. Sementara untuk struktur ekonomi di dominasi oleh pertanian, sebenarnya tidak ada yang salah selama diterapkan dengan konservasi tanah yang benar sebingga tidak mengganggu kelestarian lingkungan. Untuk DAS Solo hilir struktur ekonomi sudah diluar sektor pertanian yaitu di sektor perdagangan, hotel, restoran dan sektor industri pengolahan. Ini terlihat bahwa sektor pertanian untuk sementara ini masih belum bisa dijadikan sebagai peningkatan kesejahteraan. Secara lebih jelas tipologi sosial ekonomi dapat dilihat pada Tabel 11.

Tabel (Table) 11. Tipologi sosial ekonomi DAS Solo (Socio economic typology of Solo Watershed)

\begin{tabular}{llcccc}
\hline No & $\begin{array}{c}\text { Kabupaten/ } \\
\text { Kota } \\
(\text { No })\end{array}$ & $\begin{array}{c}\text { Kerentanan penduduk } \\
\text { terhadap lahan } \\
\text { (Population to land } \\
\text { vulnerability) }\end{array}$ & $\begin{array}{c}\text { Kerentanan } \\
\text { ekonomi } \\
\text { (Economic } \\
\text { vulnerability) }\end{array}$ & $\begin{array}{c}\text { Tipologi sosek } \\
\text { (Socio economic } \\
\text { typology) }\end{array}$ & $\begin{array}{c}\text { Keterangan } \\
\text { (Remarks) }\end{array}$ \\
\hline 1 & Boyolali & 5 & 2,5 & 3,75 & Rentan \\
2 & Karanganyar & 4 & 1,5 & 2,75 & Sedang \\
3 & Klaten & 3 & 3,5 & 3,25 & Sedang \\
4 & Sragen & 5 & 2,5 & 3,75 & Rentan \\
5 & Sukoharjo & 4 & 2,5 & 3,25 & Sedang \\
6 & Surakarta & 3 & 2 & 2,5 & Agak rentan \\
7 & Wonogiri & 5 & 4,5 & 4,75 & Sangat rentan \\
8 & Ngawi & 5 & 3 & 2,25 & Agak rentan \\
9 & Kota Madiun & 3 & 1,5 & 3,75 & Rentan \\
10 & Madiun & 2,5 & 3,5 & Rentan \\
11 & Magetan & 5 & 2 & 3,5 & Rentan \\
12 & Ponorogo & 5 & 2 & 4,25 & Rentan \\
13 & Blora & 5 & 3,5 & 2,5 & Agak rentan \\
14 & Bojonegoro & 5 & 1 & 3,25 & Sedang \\
15 & Lamongan & 4 & 1,5 & 2,5 & Agak rentan \\
16 & Tuban & 5 & 2 & 3,75 & Sedang \\
17 & Gresik & 3 & 2,32 & & Sedang \\
\hline
\end{tabular}

Sumber (Source): Analisis data (Data analysis), 2012 


\section{Kerentanan Biofisik}

\section{Tipologi Lahan}

Penutupan lahan DAS Solo diperoleh dari Peta Topografi skala 1: 250.000. Untuk klasifikasi penutupan lahan di DAS Solo terdiri dari: tubuh air (tawar dan laut), rawa, belukar/ semak, pemukiman, sawah (irigasi dan tadah hujan), kebun, hutan, dan tegalan.

\section{a. Sistem lahan}

Sistem lahan di DAS Solo didominasi oleh dataran. Sistem lahan terluas kedua adalah dataran/ lembah alluvial untuk Sub DAS Solo Hilir, sedangkan Sub DAS Solo Hulu dan Kali Madiun terluas kedua didominasi oleh perbukitan. Penyebarannya dapat dilihat pada Gambar 2 sedangkan perbandingannya dapat dilihat pada Gambar 3. Dari Gambar 3 terlihat bahwa

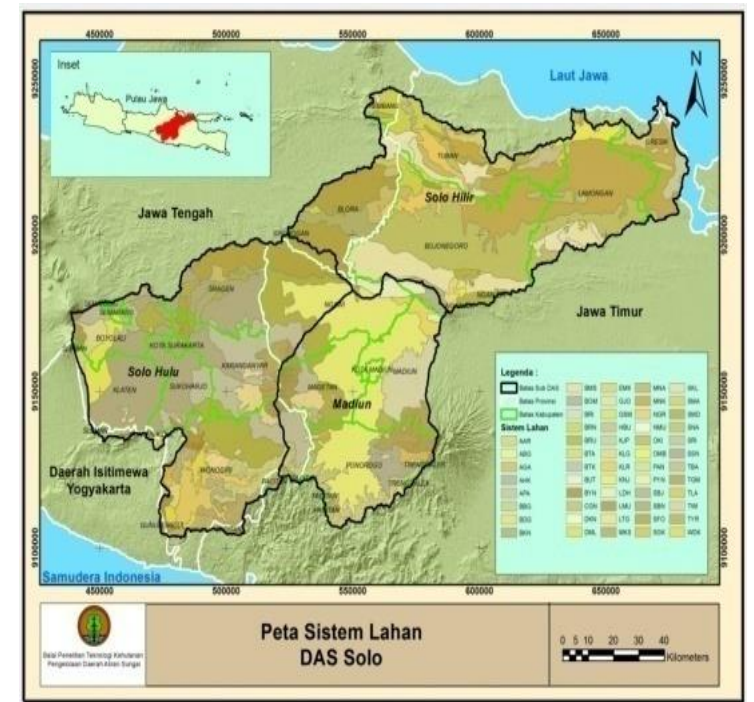

Gambar (Figure) 2. Peta sistem lahan DAS Solo (Land system map of Solo Watershed)

Sumber (Source): Balai Penelitian Teknologi Kehutanan Pengelolaan DAS (2012)
Sub DAS Solo Hilir mempunyai bentuk lahan dataran alluvial yang cukup luas. Daerah dataran alluvial ini sering tergenang banjir. Sub DAS Solo Hulu dan Kali Madiun mempunyai bentuk lahan perbukitan berpotensi untuk terjadinya erosi dan menjadi sumber sedimentasi bagi daerah hilir.

\section{b. Penutupan lahan}

Penutupan lahan di DAS Solo secara keseluruhan didominasi oleh tegal dan sawah. Di Sub DAS Solo Hulu juga didominasi oleh tegal dan sawah. Di Sub DAS Kali Madiun dan Sub DAS Solo Hilir hampir seimbang luas sawah, tegal, dan kebun. Penyebaran jenis penutupan lahan dapat dilihat pada Gambar 4 sedangkan perbandingan luas penutupan lahan pada masing-masing sub DAS dapat dilihat pada Gambar 5.

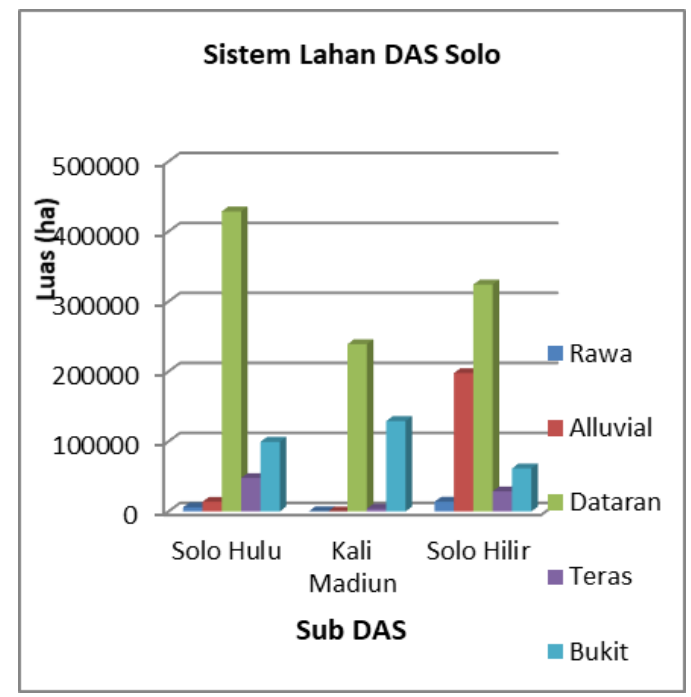

Gambar (Figure) 3. Perbandingan luas sistem lahan masing-masing Sub DAS (Comparison of land system area in each sub-watershed

Sumber (Source): Analisis data (Data analysis) 2012 


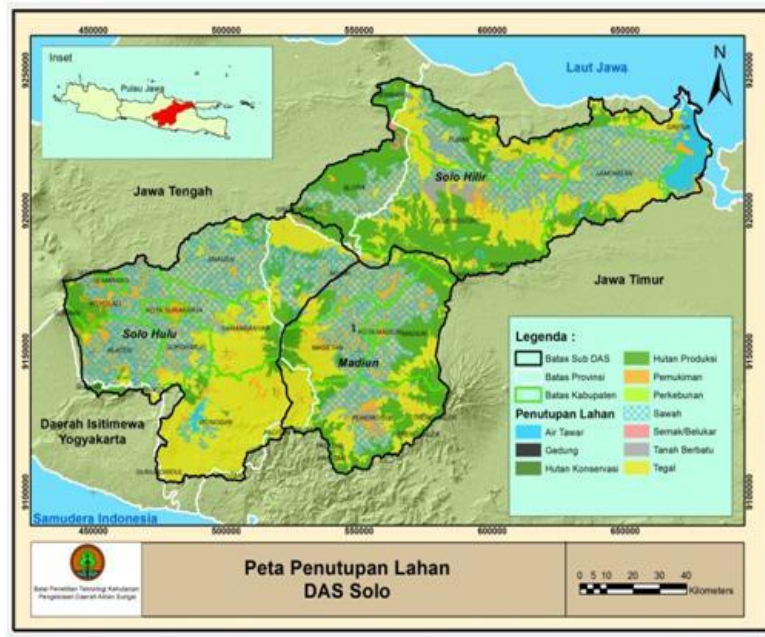

Gambar (Figure) 4. Peta jenis penutupan lahan DAS Solo (Land cover map of Solo Watershed)

Sumber (Source): Balai Penelitian Teknologi Kehutanan Pengelolaan DAS (2012)

Dari Gambar 5 terlihat bahwa penutupan lahan tegal mendominasi ketiga sub DAS yang masuk ke DAS Solo. Kondisi ini menyebabkan DAS Solo rentan terhadap terjadinya erosi apabila didukung dengan curah hujan yang cukup tinggi dan terletak pada lahan dengan kemiringan $>25 \%$. Hal yang menarik lainnya dari Gambar 5 adalah luas hutan lindungnya sangat kecil atau hampir tidak ada, sedangkan luas hutan produksi dan perkebunan di sub DAS Solo Hulu hanya 71.239 ha atau 4,5\% dari luas DAS Solo. Padahal di sub DAS Solo Hulu ini bentuk lahan pegunungan atau berbukit mencapai 99.477 ha. Dengan kata lain ada sekitar 28.238 ha lahan berbukit atau bergunung yang ditutupi oleh penggunaan lahan selain hutan atau perkebunan.

\section{c. Kerentanan lahan}

Kerentanan lahan didekati dengan tipologi lahan. Tipologi lahan diperoleh dari interaksi antara sistem lahan dan

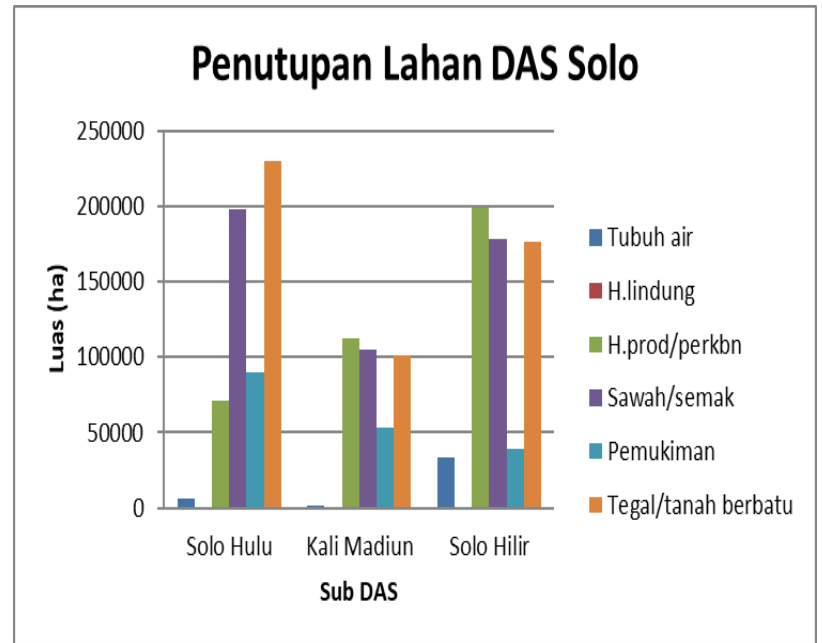

Gambar (Figure) 5. Perbandingan jenis penutupan lahan pada masing-masing Sub DAS (Comparison of land cover types in each subwatershed)

Sumber (Source): $\quad$ Analisis data (Data analysis), 2012

penutupan lahan. Berdasarkan analisis tipologi lahan diperoleh hasil kerentanan lahan dari yang tidak rentan sampai sangat rentan. Penyebaran kerentanan lahan dapat dilihat pada Gambar 6.

Dari aspek kerentanan lahan, kategori sangat rentan ada di Sub DAS Kali Madiun dan Solo Hulu (Gambar 6) dengan skor masing-masing 3,67 dan 3,63. Sub DAS

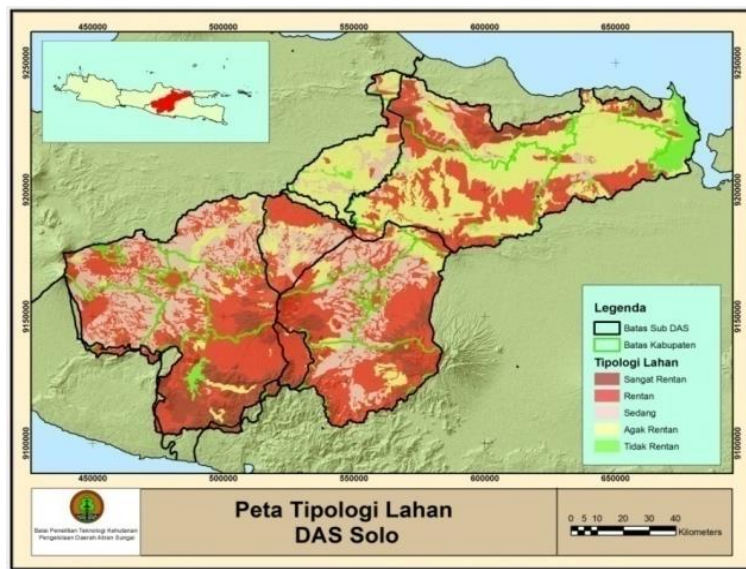

Gambar (Figure) 6. Peta kerentanan lahan DAS Solo (Land vulnerability map of Solo Watersheds)

Sumber(Source): Balai Penelitian Teknologi Kehutanan Pengelolaan DAS (2012) 
Solo Hilir masuk kategori sedang dengan skor 2,73. Secara keseluruhan kerentanan lahan dengan skor 3,34, masuk kategori sedang. Luas areal yang paling rentan terdapat di Sub DAS Solo Hulu sebesar 88.830 ha.

Kerentanan lahan pada kategori rentan dan sangat rentan di DAS Solo menyebar di seluruh DAS namun sebagian besar berada di Sub DAS Solo Hulu dan Kali Madiun. Sub DAS Solo Hulu yang sangat rentan dan rentan berada di Kabupaten Wonogiri dan Karanganyar, masingmasing menempati porsi $78 \%$ dan $79 \%$ dari luas kabupaten. Sub DAS Kali Madiun yang sangat rentan dan rentan terletak di Kabupaten Ponorogo dan Magetan, masing-masing menempati porsi $72 \%$ dan $61 \%$ dari luas kabupaten.

Sementara di DAS Solo Hilir yang rentan lahan terletak di Kabupaten Tuban dan Gresik, masing masing dengan porsi $50 \%$ dan $18 \%$ dari luas kabupaten yang masuk ke DAS Solo. Tingkat kerentanan lahan di kabupaten-kabupaten lain termasuk sedang dan rendah karena bentuk lahannya lembah alluvial dan dataran.

Dari data kerentanan lahan tersebut berimplikasi terhadap prioritas penanganan dan jenis-jenis perlakuan yang diberikan. Prioritas tinggi ditujukan pada lahan dengan tingkat kerentanan yang sangat tinggi.

\section{Tipologi Banjir}

Tipologi banjir di bedakan menjadi dua yaitu potensi pasokan air banjir dan daerah kebanjiran.

\section{a. Pasokan air banjir}

Pada umumnya curah hujan maksimum harian di DAS Solo berkisar dari 71 $\mathrm{mm} /$ hari (sedang) sampai $185 \mathrm{~mm} /$ hari (sangat tinggi), sehingga potensi pasokan air banjir di DAS Solo termasuk sedang sampai sangat rentan. Kriteria curah hujan tidak rentan jika curah hujan harian $<20$ $\mathrm{mm}$, agak rentan jika curah hujan hariannya berkisar antara $21-40 \mathrm{~mm}$, sedang jika hujannya $41-75 \mathrm{~mm}$, rentan jika hujannya 76-150 mm, dan sangat rentan jika hujannya $>150 \mathrm{~mm}$ (Paimin et. al. 2012). Tingkat kerentanan pasokan air di DAS Solo dapat dilihat pada Gambar 7.

Kerentanan pasokan air sangat tinggi dan tinggi terjadi di Sub DAS Solo Hulu dan Kali Madiun. Kondisi ini menyebabkan Sub DAS Bengawan Solo Hilir menjadi rawan kebanjiran, apalagi didukung oleh bentuk lahan yang relatif datar. Pasokan air yang sangat tinggi terjadi di Kabupaten Karanganyar dan Magetan yang terletak di

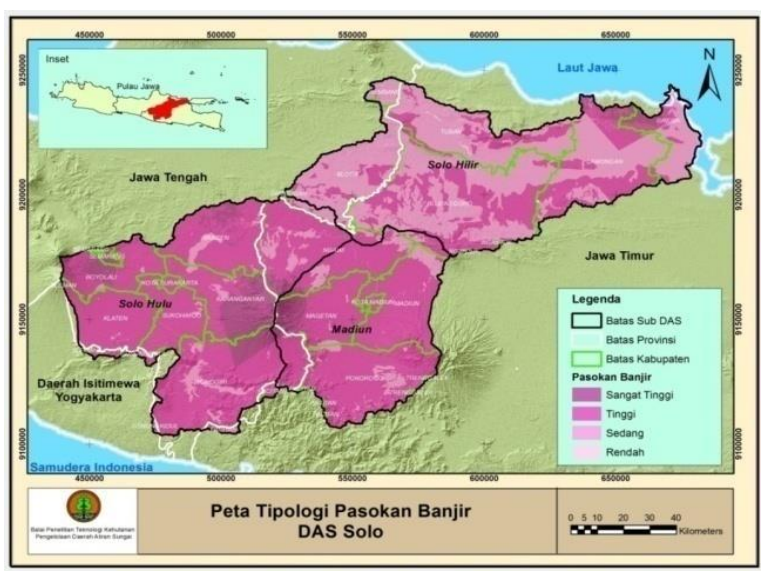

Gambar (Figure) 7. Peta kerentanan pasokan air DAS Solo (Water supply vulnerability map of Solo Watershed)

Sumber (Source): Balai Penelitian Teknologi Kehutanan Pengelolaan DAS (2012) 
lereng Gunung Lawu. Pasokan air dari tempat tersebut sangat tinggi karena hujan maksimumnya $185 \mathrm{~mm}$ dengan topografi pegunungan.

Hampir semua kabupaten di Sub DAS Solo Hulu dan Sub DAS Kali Madiun mempunyai tingkat kerentanan pasokan air banjir yang tinggi (skor 4). Mengingat kerentanan pasokan air banjir ini ditentukan oleh hujan harian maksimum, maka untuk mengatasi dampak banjir di daerah bawahnya, daerah-daerah dengan kondisi yang sangat rawan pasokan air banjir perlu dicegah dengan melakukan tindakan konservasi air yang memadai baik vegetatif maupun sipil teknis seperti penanaman pada bibir teras, pembuatan dam penahan, dam pengendali, dan sumur resapan.

\section{b. Daerah Kebanjiran}

Daerah rawan banjir di DAS Solo terutama tersebar di DAS Solo Hilir, dimana daerah-daerah tersebut mempunyai kemiringan lereng $<2 \%$ dan terletak di sekitar sungai utama dan percabangan antara anak-anak sungai Bengawan Solo. Peta Daerah Rawan Banjir dapat dilihat pada Gambar 8.

Daerah rawan banjir di DAS Solo menyebar di Kabupaten Gresik, Lamongan, Tuban, Bojonegoro, Blora, dan Sragen masing-masing sebesar $71 \%, 53 \%$, $28 \%$, 19\%, dan $9 \%$ dari luas kabupaten yang masuk ke DAS Solo. Kabupatenkabupaten lainnya mempunyai tingkat kerentanan banjir sedang sampai rendah.

Sub DAS Solo Hilir mempunyai skor yang paling tinggi untuk daerah kebanjiran $(3,32)$, sedangkan Sub DAS Kali Madiun mempunyai skor yang paling rendah yaitu

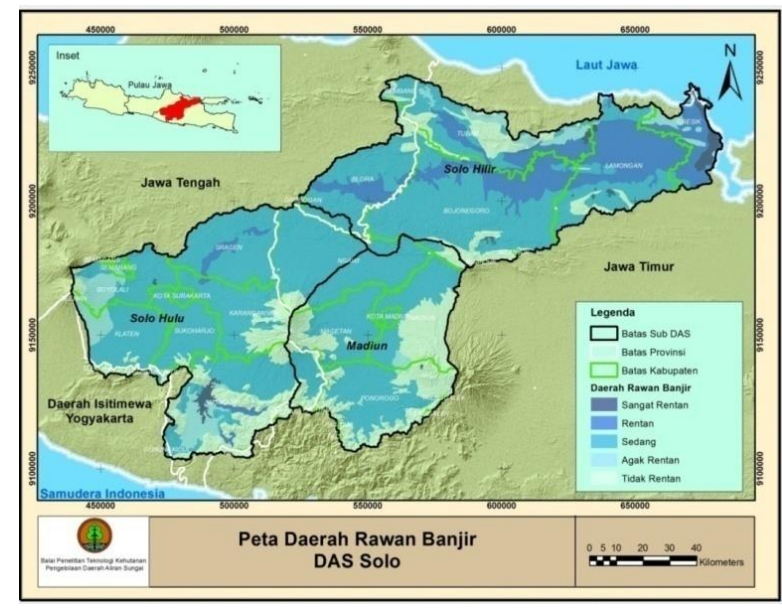

Gambar (Picture) 8. Peta daerah rawan banjir DAS Solo (Flood vulnerable areas map of Solo watershed)

Sumber (Source): Balai Penelitian Teknologi Kehutanan Pengelolaan DAS (2012)

2,94. Sub DAS Solo Hulu mempunyai skor daerah kebanjiran yang agak tinggi 3,3 karena di Sub DAS hulu ada Waduk Gajah Mungkur yang diasumsikan termasuk daerah yang rawan kebanjiran. Untuk mencegah daerah potensial rawan banjir di Sub DAS Solo Hilir perlu dilakukan perbaikan saluran drainase yang memadai serta pembuatan tanggul-tanggul di kiri kanan sungai.

\section{Kerentanan Lahan, Pasokan Air, dan Daerah Kebanjiran}

Berdasarkan analisis tipologi lahan dan banjir, kerentanan banjir paling menonjol di Sub DAS Solo Hilir, sedangkan kerentanan lahan paling menonjol di Sub DAS Solo Hulu dan Kali Madiun. Perinciannya dapat dilihat pada Gambar 9.

Dari Gambar 9 terlihat bahwa seluruh DAS Solo rentan terhadap pasokan air yang cukup tinggi dengan skor 4 . Kerentanan lahan yang cukup tinggi terjadi di Sub DAS Solo Hulu dan Kali Madiun, sedangkan di Solo Hilir kerenta- 


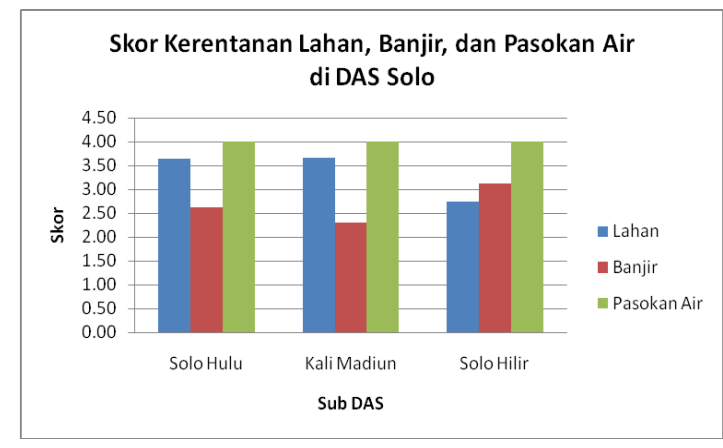

Gambar (Figure) 9. Perbandingan tingkat kerentanan lahan, banjir dan pasokan air dari masingmasing Sub DAS (Comparison of the level of vulnerability of land, flooding and water supply from each subwatershed)

Sumber (Source): Analisis data (Data analysis), 2012

nan lahannya rendah namun kerentanan daerah kebanjirannya cukup tinggi.

Dari data kerentanan tersebut terlihat bahwa adanya pasokan air dari Solo Hulu dan Kali Madiun yang cukup tinggi menyebabkan banjir di daerah hilir yang mempunyai bentuk lahan dataran dan alluvial. Dengan kondisi seperti tersebut maka pengelolaan di DAS Solo sebaiknya lebih fokus di Sub DAS Solo Hulu dan Kali Madiun untuk mengurangi pasokan air banjir sehingga banjir di daerah Solo Hilir akan berkurang. Jika yang ditangani hanya focus di daerah kebanjiran Solo Hilir maka banjir akan makin sering terjadi dan makin lama makin membesar karena daerah pasokan air banjirnya tidak tertangani.

\section{Tipologi Daerah Tangkapan Air (DTA)}

Tipologi DTA merupakan interaksi tipologi lahan dan tipologi sosial ekonomi. Nilai kerentanan daerah tangkapan air merupakan nilai rata-rata dari nilai tipologi lahan dan nilai tipologi sosial ekonomi, dan tingkat kerentanannya dengan menggunakan klasifikasi Tabel 5. Berdasarkan hasil interaksi tersebut, tipologi DTA DAS Solo masuk kategori sedang. Berdasarkan data tersebut maka permasalahan lahan yang akan diatasi juga sekaligus dapat juga mengatasi masalah sosial ekonomi. Dengan kata lain penanganan masalah lahan tidak dapat mengabaikan masalah sosial ekonomi masyarakatnya. Secara lebih jelas dapat dilihat pada Tabel 12.

\section{Tipologi DAS}

Tipologi DAS diperoleh dari hasil interaksi antara tipologi DTA dan tipologi banjir. Tipologi DTA diperoleh skore 3,32 masuk kategori sedang, tipologi banjir masuk kategori tinggi dengan skore 3,52, sehingga diperoleh tipologi DAS dengan skore 3,4 masuk kategori sedang. Dari informasi tersebut pengelolaan di DAS Solo lebih di fokuskan pada pengelolaan lahan yang bertujuan memasukkan air hujan ke dalam tanah agar aliran permukaan berkurang sehingga banjir

Tabel (Table) 12. Tipologi daerah tangkapan air DAS Solo (Catchments typology of Solo Watershed)

\begin{tabular}{llcc}
\hline No & \multicolumn{1}{c}{ Tipologi DTA } & Skor (Score) & Keterangan (Remarks) \\
& (Catchments typology of Solo Watershed) & & Sedang \\
2 & Tipologi lahan & 3,34 & sedang \\
& Tipologi sosial ekonomi & 3,31 & sedang \\
\hline
\end{tabular}

Sumber (Source): Analisis data (Data analysis), 2012 
akan berkurang. Walaupun pasokan air sudah berkurang namun di daerah hilir perlu dilakukan perbaikan sistem drainase sehingga air hujan akan lancar mengalir ke saluran-saluran.

\section{Tipologi Kewilayahan Pengelolaan DAS}

Tipologi kewilayahan pengelolaan DAS dilihat dari luas DAS dan kewilayahan administrasi dominan (Tabel 6). DAS Solo dilihat dari luas DAS lebih dari 0,5 juta ha dengan kewilayahan administrasi lintas propinsi dari Jawa Tengah dan Jawa Timur, hal ini menunjukkan skala kerentanannya adalah sangat tinggi (skor 5). Dari informasi tipologi kewilayahan pengelolaan di DAS Solo ini mempunyai potensi yang rentan karena terletak di dua propinsi dan 17 kabupaten dimana masing-masing daerah administrasi tersebut mempunyai focus atau prioritas yang berbeda-beda. Untuk mengatasi kerentanan wilayah ini sebetulnya PP 37 tahun 2012 tentang Pengelolaan DAS sudah mengantisipasi bahwa pengelolaan DAS antar propinsi dilakukan oleh Pemerintah Pusat.

\section{Kondisi Sosial Ekonomi dan Biofisik dalam Kaitannya dengan Pengelolaan DAS}

Melihat kerentanan masing-masing aspek, dimana kerentanan tipologi sosial ekonomi masuk dalam kategori sedang dan tipologi lahan masuk dalam kategori sedang, maka tipologi Daerah Tangkapan Air (DTA) (Tabel 5) DAS Solo masuk dalam kategori sedang. Tipologi pengelolaan DAS merupakan manifestasi dari tipologi DAS dan tipologi kewilayahan. Tipologi kewilayahan masuk dalam kategori sangat tinggi (skor 5) dan tipologi DAS masuk dalam kategori sedang (skor 3,4 ) sehingga tipologi pengelolaan DAS masuk dalam kategori tinggi (skor 4,2). Peta tipologi DTA dan tipologi pengelolaan DAS dapat dilihat pada Gambar 10 dan Gambar 11.

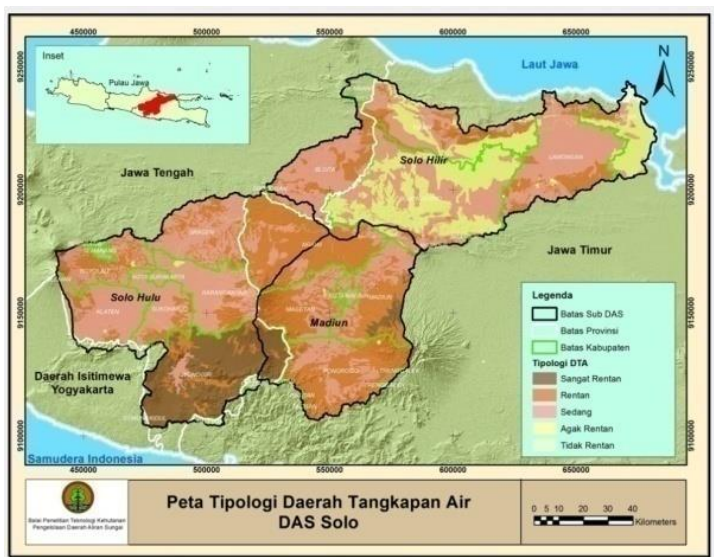

Gambar (Figure) 10. Tipologi daerah tangkapan air DAS Solo (Catchments typology of Solo Watershed)

Sumber (Source): Analisis data (Data analysis), 2012

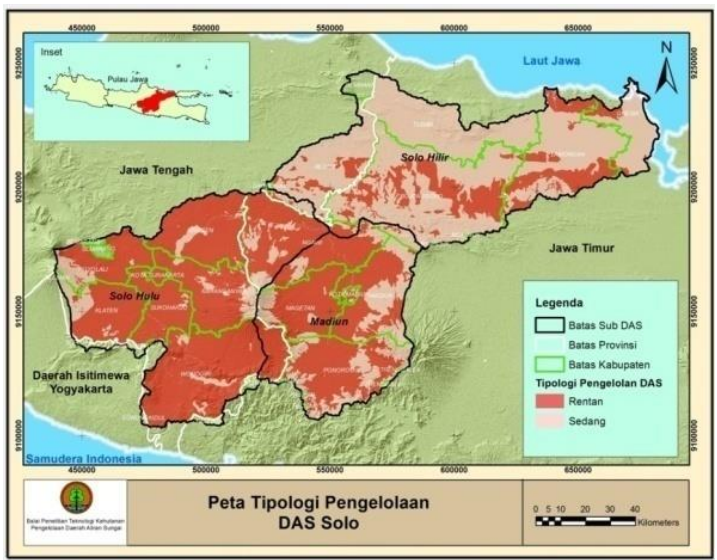

Gambar (Figure) 11. Tipologi pengelolaan DAS Solo (Typology of Solo watershed management)

Sumber (Source): Analisis data (Data analysis), 2012

Berdasarkan peta kerentanan biofisik (terutama lahan), serta kerentanan penduduk dan ekonomi, terlihat bahwa Kabupaten Wonogiri mempunyai tingkat kerentanan yang paling tinggi (sangat rentan). Sementara daerah hulu yang lain 
seperti Sragen, Boyolali, Magetan, Ponorogo, Madiun, dan Blora mempunyai tingkat kerentanan yang tinggi untuk kependudukan, ekonomi, dan lahan. Hal ini disebabkan oleh kepadatan penduduk yang tinggi, dan struktur ekonominya yang mengandalkan dari pertanian. Selain itu, karena lokasinya di hulu, maka lahan pertanian yang digunakan berbentuk perbukitan dan pegunungan sehingga sangat rentan bila digunakan untuk tanaman semusim.

Untuk mengurangi tingkat kerentanan sosial ekonomi dan lahan di daerah hulu ini maka pengembangan industri pengolahan hasil pertanian harus ditingkatkan sehingga penduduk tidak hanya tergantung pada sektor pertanian saja. Hal ini tentu saja harus menjadi perhatian Pemerintah. Untuk pola pertanian di sektor hulu perlu dilakukan perubahan pengolahan tanah yang mengurangi eksploitasi tanah, misalnya dilakukan penanaman dengan pola agroforestri dengan tanaman di bawah tegakan yang dapat meminimalkan erosi.

Berdasarkan tipologi pengelolaan DAS, DAS Solo mempunyai kategori kerentanan tinggi. Hal ini karena DAS Solo mempunyai wilayah yang luas, dan terbagi menjadi banyak kabupaten yang mempunyai kepentingan masing-masing dan mencakup lintas propinsi. . Selain itu kinerja pengelolaan DAS Solo dinilai masih rendah, terutama disebabkan oleh pengaturan atau alokasi posisi dan peran lembaga pemerintah yang kurang sesuai untuk melaksanakan pengelolaan DAS (Sudarwanto, Wijaya, \& Nugroho, 2011).

Oleh karena itu dalam pengelolaan DAS Solo diperlukan adanya koordinasi antar kabupaten sehingga Sungai Bengawan Solo memberikan banyak manfaat kepada semua kabupaten secara proporsional.. Berdasarkan kondisi kerentanan DAS Solo maka hal-hal yang perlu dilakukan dalam membangun koordinasi antar kabupaten tersebut diantaranya (1) pembentukan mekanisme cost sharing antar kabupaten yang berada di hulu dan kabupaten di hilir, (2) peningkatan koordinasi yang intensif antar kabupaten, (3) campur tangan menteri, gubernur, bupati/ walikota dan instansi terkait untuk mengatur pengelolaan DAS Solo yang dikoordinasi oleh menteri (PP 37 tahun 2012), (4) penyusunan kebijakan dan aturan yang tegas dalam mengatur pertanian yang ramah lingkungan (Saridewi, Hadi, Fauzi, \& Rusastra, 2014), (5) dilakukan tindakan konservasi tanah dan air yang memadai baik secara vegetatif maupun sipil teknis (Sallata, 2017; Darmawan, Sholichin, Limantara, \& Andawayanti, 2014).

Dilihat dari kerentanan masing-masing kabupaten baik itu kerentanan sosial ekonomi maupun kerentanan biofisik, jika koordinasi dapat berjalan dengan baik maka instansi yang bersangkutan dapat menentukan prioritas penanganan. Masalah ini memang sudah laten, tapi koordinasi inilah yang perlu ditinjau ulang agar menjadi lebih baik. Berdasarkan tipologi sosial ekonomi, yang menjadi pemicu kerentanan adalah kepadatan penduduk dan kerentanan lahan yang tinggi. Begitu juga dilihat dari kerentanan biofisiknya dimana ada daerah yang rentan banjir dan pasokan banjir.

Penanganan banjir pada daerah pemasok air akan berbeda dengan daerah 
kebanjiran. Penanganan daerah pasokan air lebih ditekankan pada menahan air di tempat tersebut, sedangkan di daerah kebanjiran lebih ditekankan pada mengalirkan air menjadi lancar (Pramono, 2013).

\section{KESIMPULAN DAN SARAN}

\section{A. KESIMPULAN}

Secara umum tipologi sosial ekonomi DAS Solo masuk dalam kategori sedang. Kabupaten yang sangat rentan adalah Wonogiri. Sementara itu Kabupaten Boyolali, Sragen, Ngawi, Madiun, Magetan, Ponorogo, dan Blora masuk dalam kategori rentan. Pemicu kerentanan sosial ekonomi adalah kepadatan penduduk yang tinggi dan kerentanan lahan yang tinggi.

Kerentanan lahan di DAS Solo masuk dalam kategori sedang. Kerentanan lahan yang paling rentan adalah di Sub DAS Kali Madiun dan Solo Hulu dengan kategori tinggi. Kerentanan banjir paling menonjol di Sub DAS Solo Hilir

Tipologi pengelolaan DAS dilihat dari tipologi kewilayahan dan tipologi DAS dimana tipologi kewilayahan masuk dalam kategori sangat tinggi dan tipologi DAS masuk dalam kategori sedang, sehingga tipologi pengelolaan DAS masuk dalam kategori tinggi.

Pengelolaan di DAS Solo lebih di fokuskan pada pengelolaan lahan yang bertujuan memasukkan air hujan ke dalam tanah agar aliran permukaan berkurang sehingga banjir akan berkurang. Model pengelolaan lahan tersebut juga harus dapat meningkatkan pendapatan masyarakat. Walaupun pasokan air akan berkurang namun di daerah hilir perlu dilakukan perbaikan system drainase sehingga air hujan akan lancar mengalir ke saluran-saluran.

\section{B. SARAN}

Penanganan kerentanan harus dilihat masing-masing kasus, tidak dapat disamaratakan biofisik dulu atau sosial ekonomi dulu. Tetapi terlebih dahulu dilihat yang prioritas harus mendapat perhatian. Oleh karena itu perlu adanya koordinasi antar instansi pemerintah dari hulu sampai hilir untuk memecahkan permasalahan pengelolaan DAS.

\section{UCAPAN TERIMA KASIH}

Kami ucapkan terima kasih kepada Balai Penelitian dan Pengembangan Teknologi Pengelolaan DAS Solo yang telah mendukung terlaksananya penelitian serta tim penelitian Pengelolaan DAS Solo Bapak Irfan Budi Pramono, Dody Yuliantoro dan Eko Priyanto sehingga penelitian berjalan dengan lancar dan pihak-pihak yang tidak dapat kami sebutkan satu persatu.

\section{DAFTAR PUSTAKA}

Ariani, R. D., \& Harini, R. (2012). Tekanan penduduk terhadap lahan pertanian di kawasan pertanian (Kasus Kecamatan Minggir dan Moyudan). Jurnal Bumi Indonesia, 1(3). http://lib.geo.ugm.ac.id/ojs/index.ph $\mathrm{p} / \mathrm{jbi} /$ article/view/110

Atmojo, S. W. (2008). Peran agroforestri dalam menanggulangi banjir dan longsor DAS. Proseding Seminar Nasional Pendidikan Agroforestry Sebagai Strategi Menghadapi Pemanasan Global di Fakultas Pertanian, UNS. Solo, 4 Maret 2008. (pp. 1-15). UNS. 
Balai Besar Wilayah Sungai Bengawan Solo. (2012). Profil pengelolaan sumber daya air wilayah Sungai Bengawan Solo tahun 2012.

Bank Indonesia. (2011). Laporan perekonomian Indonesia tahun 2011. Diakses tanggal 8 Januari 2013, https://www.bi.go.id/id/publikasi/la poran-tahunan/perekonomian/ Pages/lpi_2011.aspx

BPS. (2011a). Jawa Tengah dalam angka 2011. Diakses tanggal 8 Januari 2013, https://jateng.bps.go.id/publication/ 2011/12/28/84d9f0f207bc00e41569 a815/jawa-tengah-dalam-angka2011.html

BPS. (2011b). Provinsi Jawa Timur dalam Angka 2011. BPS. Diakses tanggal 8 Januari 2013, https://jatim.bps.go.id/ publication/2011/10/25/3a8d0e1c06 d3904ad17d3b4d/provinsi-jawatimur-dalam-angka-2011.html

BPS. (2013). Profil kemiskinan di Indonesia September 2012. Berita Resmi Statistik Badan Pusat Statistik, (06/01/Th. XVI, 2 Januari 2013), https://id.scribd.com/document/144 640762/Berita-Resmi-StatistikPerkembangan-Kemiskinan-diIndonesia-Tahun-2012

BPS. (2018). Laporan bulanan data sosial ekonomi (93rd ed.). BPS. Diakses tanggal 20 Januari 2018. https://www.bps.go.id/publication/2 018/01/05/a3050622598802891e18 dd89/laporan-bulanan-data-sosialekonomi-januari-2018.html

Budiarti, W., Gravitiani, E., \& Mujiyo. (2017). Upaya mitigasi banjir di Sub DAS Samin melalui pengembangan masyarakat tangguh bencana. Jurnal Teknologi Lingkungan, 18(2), 241250.

https://doi.org/10.29122/jtl.v18i2.96 2
Wibowo, C. A., Sayekti, W. R., \& Rispiningtati. (2014). Studi penentuan kinerja pengelolaan DAS di Sub DAS Konto Hulu. Jurnal Pengairan.

https://jurnalpengairan.ub.ac.id/inde x.php/jtp/article/view/192

Darmawan, A. R., Sholichin, M., Limantara, L. M., \& Andawayanti, U. (2014). Studi potensi tanah longsor dan upaya pengendaliannya di wilayah Sub DAS Konto Hulu. Jurnal Teknik Pengairan, 5(1), 68-78. http://www.jurnalpengairan.ub.ac.id /index.php/jtp/article/view/206

Gautama, I. (2008). Daerah Aliran Sungai (DAS), ekosistem dan pengelolaannya. Diakses tanggal 12 September 2014, http://fahutanunhas.blogspot.com/2 008/11/daerah-aliran-sungai-dasekosistem-dan.html

Krisnohadi, A. (2011). Tekanan penduduk dan trend perubahan penggunaan lahan potensial untuk pertanian di Kota Singkawang Kalimantan Barat. Prosiding Seminar Nasional Budidaya Pertanian Urgensi Dan Strategi Pengendalian Alih Fungsi Lahan Pertanian. Bengkulu 7 Juli 2011, 3643. http://repository.unib.ac.id/118/

Lukman, A., \& Wienarto, N. (2008). Pengelolaan sumber daya alam dan lingkungan DAS Brantas Hulu. Yayasan FIELD Indonesia. http://www.litbang.pertanian.go.id/ buku/membalik-kecenderungandegrad/BAB-V-6.pdf

Nugroho, S. P. (2003). Pergeseran kebijakan dan paradigma baru dalam pengelolaan daerah aliran sungai di Indonesia. Jurnal Teknologi Lingkungan P3TL-BBPT, 4(3), 136142. 
https://www.researchgate.net/public ation/265400708_PERGESERAN_KEBI JAKAN_DAN_PARADIGMA_BARU_DA LAM_PENGELOLAAN_DAERAH_ALIRA N_SUNGAI_DI_INDONESIA

Paimin, Pramono, I. B., Purwanto, \& Indrawati, D. R. (2012). Sistem perencanaan pengelolaan daerah aliran sungai. Bogor: Pusat Penelitian dan Pengembangan Konservasi dan Rehabilitasi (P3KR). http://www.fordamof.org/files/Buku_Sistem_Perencan aan_DAS2.pdf

Paimin, Sukresno, \& Purwanto. (2010). Sidik cepat degradasi Sub Daerah Aliran Sungai (SUB DAS). Badan Penelitian dan Pengembangan Kehutanan Bogor. http://www.fordamof.org/files/Sidik_Cepat_Degradasi _SubDAS.pdf

PP 37 tahun 2012. (2012). Peraturan Pemerintah no 37 tahun 2012 tentang pengelolaan daerah aliran sungai. http://www.fordamof.org/files/PP.37_2012_PENGELOL AAN_DAS_.pdf

Pramono, I. B. (2013). Cara alami atasi banjir Jakarta. https://www.repu blika.co.id/berita/jurnalismewarga/wacana/13/01/21/mgyypdcara-alami-atasi-banjir-jakarta

Purbawiyatna, A., Kartodihardjo, H., Alikodra, H. S., \& Prasetyo, L. B. (2012). Analisis kebijakan pengelolaan hutan rakyat untuk mendorong fungsi lindung. Jurnal Pengelolaan Sumber Daya Lingkungan, 1(2), 1-10. http://journal.ipb.ac.id/index.php/jps l/article/view/10655
Rahman, M. M., Harisuseno, D., \& Singgih, D. (2012). Studi penanganan konservasi lahan di Sub DAS Keduang, DAS Bengawan Solo, Kabupaten Wonogiri. Journal Teknik Pengairan, 3(2), 250-257.

http://www.jurnalpengairan.ub.ac.id /index.php/jtp/article/download/170 $/ 166$

Sallata, M. K. (2017). Pentingnya aplikasi teknik konservasi air dengan metode struktur fisik di wilayah hulu DAS. Info Teknis Eboni, 14(1), 47-62. http://balithutmakassar.org/wpcontent/uploads/2017/11/05_Pentin gnya-Aplikas-Konservasi-

Air_INFOTEKeBoni.pdf

Saridewi, T. R., Hadi, S., Fauzi, A., \& Rusastra, I. W. (2014). Penataan ruang Daerah Aliran Sungai Ciliwung dengan pendekatan kelembagaan dalam perspektif pemantapan pengelolaan usaha tani. Jurnal Forum Penelitian Agro Ekonomi, 32(2), 87102. http://ejurnal.litbang.pertanian .go.id/index.php/fae/article/view/38 10/3159

SK. 328/Menhut-II/2009. (2009). Penetapan Daerah Aliran Sungai (DAS) prioritas dalam rangka Rencana Pembangunan Jangka Menengah (RPJM) tahun 2010-2014.

Sudarwanto, A. L. S. (2015). Implementasi kelembagaan forum pengelolaan daerah aliran sungai berbasis masyarakat. Jurnal EKOSAINS, 7(3), 295-296. http://garuda.ristekdikti.go .id/journal/article/430184

Sudarwanto, A. L. S., Wijaya, M., \& Nugroho, S. (2011). Model rekonstruksi kelembagaan pengelolaan daerah aliran sungai dalam mewujudkan pelestarian fungsi ling- 
kungan hidup (Studi DAS Bengawan Solo Hulu).

https://eprints.uns.ac.id/11918/

Susetyaningsih, A. (2012). Pengaturan penggunaan lahan di daerah Hulu DAS Cimanuk sebagai upaya optimalisasi pemanfaatan sumberdaya air. Jurnal Konstruksi Sekolah
Tinggi Teknologi Garut, 10(1). https://doi.org/10.1017/ CBO9781107415324.004

Wismarini, T. D., \& Sukur, M. (2015). Penentuan tingkat kerentanan banjir secara geospasial. Jurnal Teknologi Informasi DINAMIK, 20(1), 57-76. http://www.unisbank.ac.id/ojs/index .php/fti1/article/viewFile/4630/1362 